PONTIFÍCIA UNIVERSIDADE CATÓLICA DO RIO DE JANEIRO

\title{
A percepção quanto ao estilo de liderança liberal e os reflexos na satisfação no trabalho
}

\section{Bruna de Oliveira Carneiro}

Trabalho de Conclusão de Curso

Centro de CIÊnCIAS Sociais - CCS

DEPARTAMENTO DE ADMINISTRAÇÃO

Graduação em Administração de Empresas 


\section{A percepção quanto ao estilo de liderança liberal e os reflexos na satisfação no trabalho}

Trabalho de Conclusão de Curso, apresentado ao programa de graduação em Administração da PUC-Rio como requisito parcial para a obtenção do titulo de graduação em Administração.

Orientador(a) : Marcelo Pineiro

Rio de Janeiro novembro de 2016. 


\section{Resumo}

Carneiro, Bruna. A percepção quanto ao estilo de liderança liberal e os reflexos na satisfação no trabalho. Rio de Janeiro, 2013. 49 p. Trabalho de Conclusão de Curso - Departamento de Administração. Pontifícia Universidade Católica do Rio de Janeiro.

Os líderes de uma organização exercem papel de destaque, na medida em que são responsáveis pela tomada de decisões, pela gestão de processos e de pessoas, determinando o rumo da empresa. Uma liderança ruim, além de resultar na desmotivação e insatisfação do funcionário no trabalho e afetar 0 clima organizacional, pode, inclusive, levar ao fracasso da organização. Diante desse cenário, este estudo objetivou analisar a percepção de funcionários de várias empresas quanto ao estilo de liderança liberal e seus reflexos na satisfação no trabalho, tendo como base pesquisas bibliográficas e de campo, e o resultado obtido demonstrou uma avaliação negativa.

\section{Palavras- chave}

Liderança; Motivação; Satisfação no Trabalho; Clima Organizacional

\section{Abstract}

Carneiro, Bruna. The perception on the laissez-faire leadership and its reflects on satisfaction at work. Rio de Janeiro, 2016. 49 p. Trabalho de Conclusão de Curso - Departamento de Administração. Pontifícia Universidade Católica do Rio de Janeiro.

The leaders in an organization play an important role in it since they are responsible for making decisions and also for managing processes and people, defining the company's path. A bad leadership not only results in employee demotivation and dissatisfaction at work and affects the organizational climate, but also can lead to the organization's failure. Considering this situation, this study's purpose was to analyze the perception of some employees from different companies on the laissez-faire leadership and its reflects on satisfaction at work, based on bibliographic research and survey, which resulted on a negative evaluation.

\section{Key-words}

Leadership; Motivation; Satisfaction at Word, Organizational Climate 


\section{Sumário}

1. O problema 1

1.1 Introdução 1

1.2. Objetivo final 2

1.3. Objetivos intermediários 2

1.4. Delimitação do estudo 2

1.5. Relevância do Estudo 3

2. Revisão de literatura 4

2.1. Liderança 4

2.1.1. Teorias e estilos de liderança 4

2.1.2. Liderança eficaz 6

2.2. Motivação 8

2.3. Satisfação no trabalho 11

2.4. Clima organizacional 12

$\begin{array}{ll}\text { 2.4.1. Pesquisa de clima organizacional } & 14\end{array}$

3. Metodologia 17

$\begin{array}{ll}3.1 . & \text { Tipo de pesquisa } \\ & 17\end{array}$

3.2. Universo e amostra 17

$\begin{array}{ll}\text { 3.3. Coleta de dados } & 18\end{array}$

3.4. Tratamento dos dados 19

3.5. Limitações do método 19

4. Apresentação e análise dos resultados 20

4.1. Descrições dos resultados 20

4.1.1. Perfil dos respondentes 20

4.1.2. Respostas sobre liderança e satisfação no trabalho 21

5. Conclusões e recomendações para novos estudos 34

5.1. Conclusões 34

5.2. Recomendações para novos estudos 35 
6. Referências Bibliográficas

7. Apêndice 1 - Questionário

\section{Lista de Figuras}

Figura 1: Hierarquia das necessidades de Maslow.

\section{Lista de Gráficos}

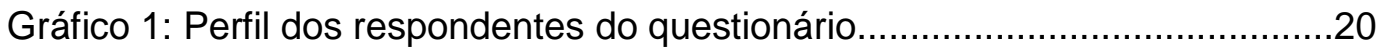

Gráfico 2: Estilo de liderança do gestor dos respondentes do questionário........21

\section{Lista de Quadros}

Quadro1: Estilos de liderança de Chiavenato .5 


\section{Lista de Tabelas}

Tabela 1: Percepção dos respondentes quanto aos estilos de liderança ...........22

Tabela 2: Percepção dos respondentes quanto ao estilo de liderança liberal.....23

Tabela 3: Percepção e satisfação dos respondentes com gestor autocrático em relação a seu gestor e às políticas de liderança em sua empresa......................24

Tabela 4: Percepção e satisfação dos respondentes com gestor democrático em relação a seu gestor e às políticas de liderança em sua empresa......................26

Tabela 5: Percepção e satisfação dos respondentes com gestor liberal em relação a seu gestor e às políticas de liderança em sua empresa......................27

Tabela 6: Contribuição do fator "liderança" para a satisfação no trabalho...........28

Tabela 7: Fatores que mais contribuem para a satisfação no trabalho...............29

Tabela 8: Características que mais se destacam em um bom líder....................30

Tabela 9: Características que mais se destacam em um mau gestor..................31

Tabela 10: Percentual de respondentes que identificam, em seu gestor, a característica destacada por eles na pergunta anterior .32 


\section{O Problema}

\subsection{Introdução}

Uma organização empresarial é composta por diversos departamentos representados numa estrutura organizacional também conhecida como organograma - que são comandados por líderes formais, ocupantes de uma função, responsáveis não apenas pela tomada de decisões da área na qual estão inseridos, mas também pela gestão de sua equipe.

Por influenciarem diretamente nos resultados da empresa, determinando o rumo que ela irá seguir através da tomada de decisão, o papel do líder é de grande importância, porém nada simples. Devem munir não apenas do conhecimento da área de atuação, mas, também, de habilidades e atitudes. Um gestor com grande conhecimento técnico, mas com poucas habilidades em lidar com pessoas, pode não apresentar um bom desempenho à organização, mesmo tomando as decisões corretas. Funcionários insatisfeitos com a liderança podem apresentar desmotivação no trabalho e, consequentemente, queda na qualidade e na produtividade.

A questão da liderança é um dos fatores que compõem o clima organizacional e, por isso, é um item que está presente nas pesquisas de clima ou de ambiência - das empresas. O índice de satisfação com a liderança deve ser mensurado, analisado e, em casos de desfavorabilidade, ações devem ser tomadas para que o problema seja corrigido. E o resultado da percepção dos funcionários quanto à liderança está relacionada ao estilo de liderança adotado pelo líder: autocrático, democrático ou liberal.

De acordo com o SEBRAE (2015), cada um dos três estilos de liderança influencia, de forma distinta, o ambiente de trabalho, o comportamento dos profissionais e o desenvolvimento das atividades. Portanto, é importante que o gestor saiba observar a situação na qual está inserido e adotar o estilo de liderança mais adequado, de acordo com a maturidade dos profissionais que comanda e o tipo de atividade executada.

O estilo liberal - conhecido também como laissez-faire, termo em francês que significa "deixe fazer" - pode parecer, a princípio, simplesmente pela ideia de liberdade, o mais desejado por uma equipe de profissionais conscientes de 
sua capacidade técnica e de autogerenciamento. Entretanto, o quanto que o excesso de liberdade permitido pelo líder liberal pode prejudicar as relações de trabalho?

\subsection{Objetivo final}

O objetivo final deste trabalho é apresentar a percepção de funcionários que vivenciam variados estilos de liderança, oriundos de empresas privadas ou da administração pública, quanto ao gestor com postura de liderança liberal e os reflexos nos níveis de satisfação do trabalho.

\subsection{Objetivos intermediários}

Para que se possa atingir o objetivo final, será necessário passar pelas seguintes etapas, tendo-as como objetivos intermediários:

- Identificar e comparar as principais características dos estilos de liderança autocrática, democrática e liberal;

- Identificar os fatores que contribuem para a satisfação do empregado no ambiente de trabalho, com base no estudo do conceito de motivação e sua relação com o clima organizacional;

- Elaborar a pesquisa quantitativa e selecionar, de forma aleatória, os funcionários respondentes;

- Interpretar o resultado da pesquisa e verificar a percepção dos respondentes quanto ao estilo de liderança liberal;

Tendo concluído essas etapas, chegar-se-á a uma conclusão e o objetivo final será alcançado.

\subsection{Delimitação do Estudo}

Para alcançar os objetivos intermediários e final deste estudo, foram entrevistados funcionários de diferentes empresas, com gestores de variados estilos de liderança, e, por fim, os resultados foram comparados para que fosse possível verificar eventuais diferenças de opinião. Esse público é formado, majoritariamente, por alunos de Administração da PUC-Rio e demais pessoas da rede de relacionamento da autora deste trabalho.

Não foram divulgados os nomes dos funcionários entrevistados nem das empresas às quais estão vinculados por motivo de privacidade. 


\subsection{Relevância do Estudo}

O assunto "liderança" está diretamente relacionado ao ativo principal de qualquer organização: as pessoas. Dessa forma, os resultados de uma má gestão, que inclui o gerenciamento desses ativos, podem ir além da insatisfação dos funcionários, podendo levar ao fracasso da empresa.

A pouca importância que alguns gestores dão aos recursos humanos, incluindo a gestão de pessoas, é um grande problema presente nos ambientes corporativos na medida em que resulta em insatisfação e desmotivação, podendo refletir no clima organizacional. Com isso, percebe-se a necessidade de se implementar medidas de conscientização desses gestores, com base nos resultados obtidos em pesquisas de ambiência, destacando erros de gestão e propondo melhorias.

Para que seja possível a realização de trabalho de conscientização e correção na liderança desses gestores, tornam-se cruciais a realização e a publicação de estudos na área de recursos humanos, na qual o tema "liderança" está inserido, justificando a relevância deste trabalho, com foco no estilo de liderança liberal. 


\section{Revisão de literatura}

\subsection{Liderança}

De acordo com a definição de Robbins, Judge e Sobral (2010), liderança é a capacidade de influenciar um grupo de pessoas com o propósito de atingir objetivos e alcançar metas.

Já Chiavenato (2005) define como um fenômeno de influência interpessoal - característico e exclusivo de grupos sociais - que ocorre em determinadas situações através de um processo de comunicação para a consecução de objetivos específicos.

Bergamini (1997) enxerga dois viés presentes na maioria das definições sobre o tema: a liderança como um fenômeno grupal e a liderança como processo de influência exercida intencionalmente pelo líder em relação a seus liderados.

Cavalcanti et al. (2009) acredita ser mais fácil reconhecer um líder do que definir o conceito de liderança, mas que a definição mais comum, porém, referese à capacidade de influenciar pessoas - como pode ser constatado pelas definições dos autores supracitados.

Yulk (2013) diz que os pesquisadores definem liderança de acordo com suas perspectivas individuais e essas definições diferem em muitos aspectos, incluindo quem exerce influência e seu propósito, bem como a maneira como a influência é exercida e seus resultados. Além disso, muitas das vezes se confunde o conceito de liderança com outros termos imprecisos como poder, autoridade, administração, controle e supervisão.

Tendo em vista certa complexidade no conceito de liderança, estudos passaram a ser cada vez mais aprofundados. Hoje, já existem diversas teorias desenvolvidas pelas escolas de pensamento em liderança que ajudam a explicar melhor o assunto.

\subsubsection{Teorias e estilos de liderança}

Apesar das diversas abordagens teóricas de liderança, a maioria dos autores cita as teorias dos traços, as teorias comportamentais e as 
contingenciais, nas quais estão inseridas outras diversas teorias, no objetivo de desenvolver o conceito sob os mais variados pontos de vista.

As teorias dos traços trazem a ideia de que líderes possuem qualidades e características pessoais específicas - traços físicos, intelectuais, sociais e direcionados para tarefa - que os diferem de não líderes. Os traços físicos são aqueles relacionados à aparência, energia e força física; os intelectuais, à adaptabilidade, entusiasmo, autoconfiança e coeficiente intelectual; os sociais, aos aspectos de cooperação, habilidades interpessoais e administrativas; e, por fim, os direcionados para a tarefa, às características de impulso de realização, persistência e iniciativa (VERGARA, 2009).

Há estudos que apontam que a extroversão, porém de forma moderada, é o traço mais importante do líder eficaz. A capacidade de cumprir compromissos, a criatividade, flexibilidade, a abertura a novas experiências e a inteligência emocional também são algumas das principais características demonstradas por líderes eficazes. Entretanto, o fato de um indivíduo apresentar esses traços e ser considerado líder não significa que será bem sucedido em liderar pessoas no alcance de seus objetivos (ROBBINS; JUDGE; SOBRAL, 2010).

As teorias comportamentais, por outro lado, trazem a ideia de que os líderes se comportam de maneira específica, diferindo-os dos não líderes. Dentre as diversas abordagens dentro das teorias comportamentais, estão os estilos de liderança. Chiavenato (2005) divide os estilos de liderança em três: autocrático, democrático ou liberal. Para melhor ilustrar as diferenças entre os estilos de liderança, segue quadro destacando as características principais de cada.

Quadro 1: Estilos de liderança de Chiavenato (continua)

\begin{tabular}{|c|c|c|c|}
\cline { 2 - 4 } \multicolumn{1}{c|}{} & Autocrático & Democrático & Liberal \\
\hline $\begin{array}{c}\text { Tomada de } \\
\text { decisões }\end{array}$ & $\begin{array}{c}\text { Apenas o líder decide e } \\
\text { fixa diretrizes, sem } \\
\text { qualquer participação } \\
\text { do grupo. }\end{array}$ & $\begin{array}{c}\text { As diretrizes são } \\
\text { debatidas e decididas } \\
\text { pelo grupo que é } \\
\text { estimulado e assistido } \\
\text { pelo líder. }\end{array}$ & $\begin{array}{c}\text { Total liberdade para a } \\
\text { tomada de decisões } \\
\text { grupais ou individuais, } \\
\text { com participação } \\
\text { mínima do líder. }\end{array}$ \\
\hline $\begin{array}{c}\text { Programação } \\
\text { dos trabalhos }\end{array}$ & $\begin{array}{c}\text { Oxecução das tarefas, } \\
\text { providências para a } \\
\text { uma por vez, na } \\
\text { medida em que são } \\
\text { necessárias e de modo } \\
\text { imprevisível pelo grupo. }\end{array}$ & $\begin{array}{c}\text { O próprio grupo esboça } \\
\text { providências e técnicas } \\
\text { para atingir o alvo com } \\
\text { o aconselhamento do } \\
\text { técnico do líder. As } \\
\text { tarefas ganham novos } \\
\text { contornos com os } \\
\text { debates. }\end{array}$ & $\begin{array}{c}\text { A participação do líder } \\
\text { no debate é limitada, } \\
\text { apresentando apenas } \\
\text { alternativas ao grupo, } \\
\text { esclarecendo que } \\
\text { poderia fornecer } \\
\text { informações desde que } \\
\text { solicitadas. }\end{array}$ \\
\hline
\end{tabular}


Quadro 1: Estilos de liderança de Chiavenato (conclusão)

\begin{tabular}{|c|c|c|c|}
\hline & Autocrático & Democrático & Liberal \\
\hline $\begin{array}{l}\text { Divisão do } \\
\text { trabalho }\end{array}$ & $\begin{array}{l}\text { O líder determina qual } \\
\text { a tarefa que cada um } \\
\text { deverá executar e qual } \\
\text { seu companheiro de } \\
\text { trabalho. }\end{array}$ & $\begin{array}{l}\text { A divisão das tarefas } \\
\text { fica a critério do grupo } \\
\text { e cada membro tem } \\
\text { liberdade de escolher } \\
\text { seus próprios colegas. }\end{array}$ & $\begin{array}{l}\text { Tanto a divisão das } \\
\text { tarefas, como a } \\
\text { escolha dos } \\
\text { companheiros fica } \\
\text { totalmente a cargo do } \\
\text { grupo. }\end{array}$ \\
\hline $\begin{array}{l}\text { Participação } \\
\text { do líder }\end{array}$ & $\begin{array}{l}\text { O líder é pessoal e } \\
\text { dominador nos elogios } \\
\text { e nas críticas ao } \\
\text { trabalho de cada um. }\end{array}$ & $\begin{array}{l}\text { O líder procura ser um } \\
\text { membro normal do } \\
\text { grupo. É objetivo e } \\
\text { estimula com fatos, } \\
\text { elogios ou críticas. }\end{array}$ & $\begin{array}{l}\text { O líder não faz } \\
\text { nenhuma tentativa de } \\
\text { avaliar ou regular o } \\
\text { curso das coisas. Faz } \\
\text { comentários apenas } \\
\text { quando perguntado. }\end{array}$ \\
\hline
\end{tabular}

Fonte: CHIAVENATO (2005, p.187)

Com base na análise dos estilos de liderança acima apresentados, percebe-se que, nesse tipo de caracterização, há uma escala de rigor quanto à participação do líder nos processos, na divisão e na programação do trabalho, e na tomada de decisão, sendo o estilo autocrático o mais rígido e o liberal, o mais brando.

Vergara (2009) simplifica a definição desses três estilos de liderança ao dizer, numa linguagem popular, que o autocrático é aquele que representa o ditado de que "manda quem pode, obedece quem tem juízo"; o democrático é o que busca a participação; e o liberal - ou laissez-faire - é aquele conhecido por "deixar rolar".

A classificação por estilo de liderança vai além da simples tipificação do comportamento e das atitudes tomadas pelo líder em cada situação, seja no que se refere à tomada de decisão, à programação dos trabalhos, à divisão do trabalho ou à participação do líder, pois irá influenciar o comportamento da equipe, a motivação e a satisfação no trabalho, a produtividade e a qualidade das tarefas executadas, de acordo com a eficácia da liderança.

\subsubsection{Liderança eficaz}

A liderança eficaz é, normalmente, medida de acordo com a contribuição percebida do líder para a qualidade dos processos de seu grupo, ou seja, com o quanto que o líder contribui para a coesão, cooperação, compromisso e autoconfiança do grupo em alcançar seus objetivos; incentiva a solução de 
problemas e a tomada de decisões; e ajuda a resolver conflitos de forma construtiva (YUKL, 2013).

A relação da eficácia do desempenho do grupo com o estilo de liderança e o grau de controle proporcionado pela situação é explicada pela Teoria de Contingência de Fiedler. Segundo essa linha de pensamento, é preciso levar em consideração três dimensões para que se tenha uma liderança eficaz: a relação líder-liderados, o grau de confiança, credibilidade e respeito entre líderes e liderados; a estrutura da tarefa, o grau de estruturação e formalização dos procedimentos e tarefas; e o poder da posição, que é ou grau de influência ou poder que um líder possui (ROBBINS; JUDGE; SOBRAL, 2010).

Robbins, Judge e Sobral (2010) definem poder como sendo a capacidade quem uma pessoa tem de influenciar o comportamento de outra pessoa e fazê-la com que ela aja de acordo com sua vontade. Essa definição é diferente de autoridade, que, segundo Yukl (2013), envolve direitos, prerrogativas, obrigações e tarefas associadas a certas posições numa organização ou sistema social.

Vergara (2009, p. 148) enxerga a relação entre liderança, motivação e poder ao afirmar que, "para que um líder exerça seu poder de influência sobre uma pessoa, precisa, no mínimo, identificar suas motivações".

No ambiente organizacional, as relações de poder são constantes e em diferentes níveis e estilos, a depender da fonte de poder. O poder de influência formal é conhecido também como autoridade, dotado por alguém em virtude de função gerencial exercida. Por outro lado, há aqueles que não possuem o poder de influência formal, não exercem função de chefia, mas são reconhecidos pelo gestor e pelos colegas de trabalho - como líderes informais.

Nesse sentido, Yukl (2013) ressalta que uma pessoa pode ser um líder sem ser um gerente, a exemplo do líder informal, da mesma forma que uma pessoa pode ser gerente sem liderar, até mesmo porque existem gerentes sem subordinados.

Yukl (2013) vai além ao distinguir líderes de gerentes - no que diz respeito a valores e personalidade - ao dizer que, enquanto gestores valorizam estabilidade, ordem e eficiência e são impessoais, avessos ao risco e focados no resultado de curto prazo, líderes valorizam flexibilidade, inovação e adaptação, são preocupados com pessoas da mesma forma que se preocupam com resultados econômicos e possuem uma perspectiva de longo prazo em relação a objetivos e estratégias.

O domínio de espaços de poder é a forma de conflitos mais camuflada nas organizações e, também, a mais difícil de ser administrada porque requer 
sensibilidade para os aspectos políticos envolvidos, apresentando-se, nitidamente, em todos os tipos de organizações - empresas familiares, multinacionais, estatais e da administração direta -, porém de forma diferente em cada uma delas (CASTILHO, 2005).

Bergamini e Coda (1997) também reconhecem a relação de líderes e liderados como sendo uma fonte de poderosas tensões internas dentro das situações de liderança por se tratar de um fenômeno de interação entre pessoas.

Portanto, a busca pela liderança eficaz pode ser visto como um grande desafio. A liderança tenderá à ineficácia se a relação entre líder e liderados não for positiva, ou se houver algum problema na estrutura das tarefas, ou se o grau de influência que um gestor possui for inadequado ao ambiente organizacional onde está inserido.

\subsection{Motivação}

Chiavenato (2005) entende que a motivação é o estado de espírito que impulsiona uma pessoa a agir de determinada forma, influenciada por estímulos externos ou por seus processos mentais, sempre objetivando atingir uma meta. Esse esforço feito para o alcance de um objetivo irá, necessariamente, refletir em seu comportamento de forma positiva ou negativa.

Griffin e Moothead (2006, p. 98) acrescentam que "motivação é um conjunto de forças que leva as pessoas a se engajar numa atividade em vez de outra".

Stoner e Freeman (1999 apud CAVALCANTI et al, 2009, p. 86) acreditam que "motivação refere-se aos fatores que provocam, canalizam e sustentam o comportamento de um indivíduo".

Lopes (1980, p. 10) afirma que "motivação é uma variável interveniente porque não pode ser vista, ouvida ou tocada: somente pode ser inferida por meio do comportamento", significando que somente observando seu comportamento é que se pode dizer o quão motivada essa pessoa está.

Silva e Rodrigues (2007) acrescenta que o estudo da motivação possibilita a busca por explicações de um dos maiores mistérios da existência humana: suas próprias ações, que demonstrarão determinado comportamento de acordo com a motivação por um desejo de atingir um objetivo.

Bergamini e Coda (1997) sintetizam, afirmando que a motivação é definida como uma inclinação para a ação que tem origem em um motivo, sendo 
esta uma necessidade, e, por não ser possível criar necessidades em outra pessoa, concluem que uma pessoa não pode motivar a outra.

Embora o tema "motivação" seja de amplo significado e, portanto, de difícil definição, percebe-se uma grande semelhança na abordagem dos autores, onde se confirma uma estreita relação conceitual e prática entre motivação, comportamento e satisfação de necessidades, não cabendo a existência de motivação sem um objetivo a ser alcançado.

A relação de motivação e comportamento presente na definição dos autores explica-se pelo fato de que o comportamento, caracterizado por uma série de atividades, é a consequência da motivação (BROXADO, 2001).

Apesar dessa definição, não se trata de um processo por etapas com um resultado comportamental previsível simplesmente porque os indivíduos são diferentes entre si. Esse argumento é corroborado por Vergara (2009) ao explicar que a motivação é algo absolutamente intrínseco, algo que vem de dentro da pessoa de acordo com suas necessidades pessoais.

$E$, por serem diferentes, os mesmos fatores internos e externos vivenciados por um grupo de pessoas podem surgir efeitos diferentes no comportamento de cada um, demonstrando diferentes graus de motivação em relação a um mesmo objetivo, por exemplo. A subjetividade do assunto faz com que surjam diversas teorias que visam explicar a questão da motivação principalmente no ambiente corporativo.

Há diversas teorias motivacionais que podem ser consideradas na explicação da relação existente entre os conceitos de motivação e liderança. Entre as teorias clássicas de motivação, está a de Maslow, que estabelece uma hierarquia de necessidades, divididas em cinco categorias - fisiológica, segurança, social, estima e autorrealização. As necessidades fisiológicas e de segurança são consideradas necessidades de nível inferior ou primárias, por serem fundamentais à natureza humana e que, para serem alcançadas, dependem de fatores externos, como o salário e a estabilidade no emprego. Já as necessidades sociais, de estima e autorrealização são consideradas de nível superior ou secundárias e que dependem do esforço do próprio indivíduo para que sejam alcançadas. Devido ao conceito hierárquico trazido por essa teoria, estabelece-se a ideia de que, a partir do momento em que uma necessidade é satisfeita, ela deixa de ser objeto de motivação e o indivíduo passa a almejar a próxima necessidade da cadeia piramidal (ROBBINS; JUDGE; SOBRAL, 2010), conforme ilustrado a seguir. 
Figura 1: Hierarquia das Necessidades de Maslow

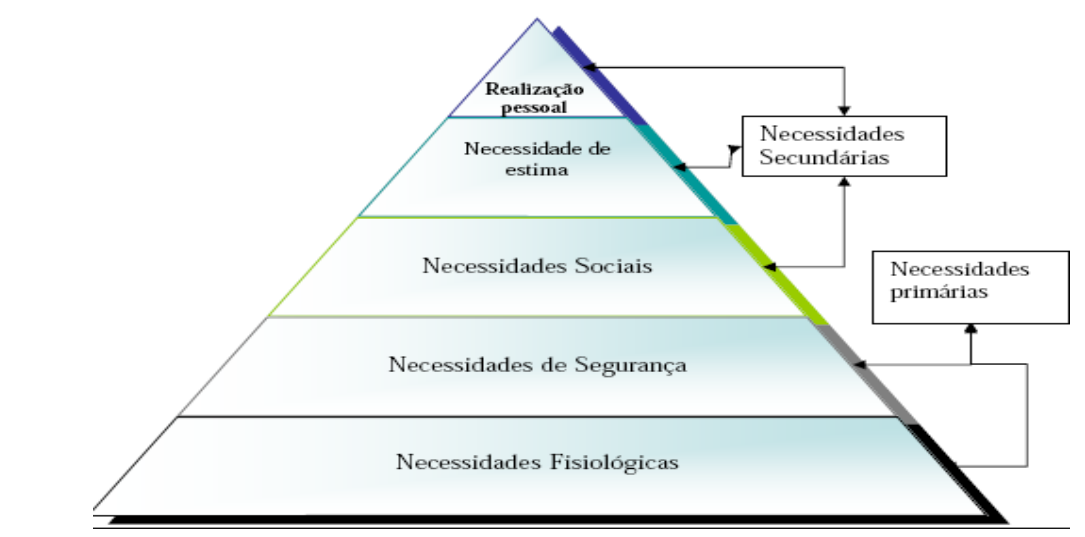

Fonte: CHIAVENATO (2005, p.253)

Outra teoria clássica de motivação bastante relevante é a de Douglas McGregor, que divide o comportamento dos funcionários de acordo com duas Teorias, denominadas de $\mathrm{X}$ e $\mathrm{Y}$. Pela Teoria $\mathrm{X}$, os funcionários são preguiçosos, não gostam de trabalhar e evitam responsabilidade. A Teoria $Y$ traz uma ideia totalmente oposta, na qual os funcionários são criativos, gostam de trabalhar e buscam responsabilidade (ROBBINS; JUDGE; SOBRAL, 2010).

Conforme Silva e Rodrigues (2007), saber identificar o tipo de perfil de um funcionário é importante para o gestor, pois, além poder selecionar melhor sua equipe, poderá adotar o estilo de liderança mais adequado.

Sob a ótica da Teoria dos Dois Fatores de Herzberg, que reconhece o ambiente de trabalho como produtor de satisfação ou insatisfação, há dois tipos fatores orientadores do comportamento humano, classificados como higiênicos ou motivacionais. Segundo a Teoria, os fatores higiênicos são aqueles relativos ao contexto do cargo e como a pessoa se sente em relação à empresa e, por isso, são considerados extrínsecos. Quando esses fatores são inadequados sob o ponto de vista do funcionário, geram insatisfação. Já os fatores motivacionais são aqueles relativos ao conteúdo do cargo ocupado pelo próprio funcionário. São fatores intrínsecos, que geram satisfação quando adequados (CHIAVENATO, 2005).

Com base nessa definição e na concepção de que a liderança é um fator inerente ao ambiente de trabalho em si, essencialmente extrínseco, pode-se afirmar que o estilo de liderança de um gestor é um fator higiênico, que gera insatisfação quando inadequado. Importante ressaltar que, quando o estilo de liderança é adequado, não gera satisfação, mas simplesmente não gera insatisfação. A partir dessa constatação, apesar das três teorias clássicas de 
motivação apresentadas explicarem bem o conceito de motivação, embora cada uma a partir de um ponto de vista específico, a Teoria dos Dois Fatores de Herzberg é a que melhor explica a relação de liderança e satisfação no trabalho.

\subsection{Satisfação no trabalho}

Até o momento, falou-se nos fatores que podem trazer satisfação ou insatisfação no trabalho com base em teorias motivacionais. A grande dificuldade, porém, talvez devido à subjetividade do assunto, está em medir o grau de satisfação ou insatisfação que uma determinada condição pode trazer e o quanto que isso pode afetar, positiva ou negativamente, o funcionário, suas relações de trabalho e o ambiente em si. É difícil mensurar porque, mesmo que o número de fatores que trazem satisfação seja maior que os que trazem insatisfação, cada fator analisado pode ter um peso diferente na percepção individual.

Rodrigues (1994, p. 56) afirma que "o grau de expectativa do indivíduo quanto a uma melhor qualidade de vida no trabalho varia com o grau de instrução", já que estudos têm mostrado que indivíduos com menor grau de instrução formal tendem a aceitar mais as condições impostas pela organização e não se sentirem insatisfeitos com isso do que aqueles com maior grau de instrução.

O que se sabe sobre os efeitos da insatisfação do trabalho, pelo pouco que se tem mapeado nas empresas brasileiras, são as consequências negativas ligadas ao comprometimento da saúde física e mental dos empregados, stress, faltas, baixa produtividade e desempenho no trabalho, inércia organizacional e dificuldade de implantação eficaz de programas de melhoria de qualidade (BERGAMINI e CODA, 1997).

Cada pessoa pode ter diferentes reações quando estão insatisfeitas no trabalho. Robbins, Judge e Sobral (2010) listam quatro tipos de respostas: saída, voz, lealdade ou negligência. O funcionário insatisfeito poderá pedir demissão e procurar um novo emprego; buscar melhores condições de trabalho por meio de propostas de melhoria a seus gestores e/ou representantes sindicais; esperar por melhores condições de trabalho por confiar na empresa e acreditar que as coisas irão melhorar; ou permitir que as condições de trabalho continuem ruins, mas, em contrapartida, irá demonstrar sua insatisfação com queda na produtividade e na assertividade. 
Qualquer que seja a resposta ao ambiente insatisfatório, todas geram certo tipo de desconforto para a pessoa que irá tomar alguma atitude. Ter de procurar um novo emprego, iniciar uma nova vida profissional, adaptar-se a uma nova renda salarial, propor melhorias a um superior hierárquico faz com que seja preciso sair da chamada "zona de conforto". Não fazer nada, permanecendo na "zona de conforto", é ruim da mesma forma, pois a melhoria esperada pode não acontecer e, inevitavelmente, poderá ficar ainda mais decepcionado e insatisfeito.

Como já explicado, a insatisfação pode levar à improdutividade se 0 funcionário optar por ser negligente à situação. Não coincidentemente, a satisfação está diretamente ligada à produtividade. Estudos comprovam a forte correlação entre satisfação no trabalho e desempenho no âmbito individual e no organizacional, tanto que organizações com maior número de funcionários satisfeitos tendem a ser mais eficientes em relação às com menor número (ROBBINS; JUDGE; SOBRAL, 2010).

Por esse motivo, Nadler e Lawler (1983 apud RODRIGUES, 1994) afirmam que a satisfação do indivíduo provocada pela qualidade de vida no trabalho é a grande esperança das organizações para atingirem altos níveis de produtividade.

Se, segundo Rodrigues (1994, p. 43), “a organização não cria uma estrutura e não dá meios para que o indivíduo tenha um bom nível de qualidade de vida no trabalho", fazendo com que se comportem com indolência, passividade, má vontade, resistência à mudança, tendência a aderir aos demagogos e exigências exageradas de benefícios econômicos, alcançar e manter a satisfação no trabalho pode ser considerado um grande desafio.

Embora os conceitos de motivação e satisfação sejam analisados individualmente, com base na situação de cada pessoa, nas suas necessidades pessoais e percepção quanto aos meios para se atingir um determinado objetivo, determinando, assim, seu grau de satisfação com o trabalho, o conjunto das motivações individuais no ambiente de trabalho poderá refletir no todo, no clima da organização.

\subsection{Clima organizacional}

Segundo Chiavenato (2009, p.88), entende-se por clima organizacional como sendo "o sentimento transmitido pelo local físico, como os participantes interagem, como as pessoas tratam os outros, clientes, fornecedores etc.". 
Ferreira (2013, p. 47) traduz esse sentimento como sendo "a qualidade do ambiente organizacional que é percebida ou experimentada por seus integrantes e influencia o seu comportamento".

Oliveira (1995) ressalta que o clima interno é o estado da empresa em dado momento, moldado pelas reações ou perspectivas dos funcionários em relação às decisões e ações pretendidas ou praticadas pela empresa, suscetível a influências internas ou externas à empresa e que, por esse motivo, é passível de alteração mesmo em um espaço curto de tempo.

Luz (1995) segue essa mesma linha ao dizer que o clima organizacional é composto pelas diferentes percepções dos funcionários em relação ao ambiente de trabalho que irão refletir o comportamento organizacional. Em outras palavras, é o que se conhece como ambiente de trabalho.

Broxado (2001) acrescenta que o clima vai ser medido de acordo com fatores como o nível de qualidade de integração interna de todos que compõem a empresa, bem como a existência de confiança, descontração e prazer ou desconfiança, tensão e conflitos, por exemplo.

Percebe-se, nessas definições de clima, o papel fundamental exercido pelos colaboradores da empresa. Por serem indivíduos, com diferentes crenças e valores e movidos por emoções e sentimentos, sendo estes estados psicológicos individuais, fica claro afirmar que a percepção de realidade da empresa e seu clima são influenciados pelo componente afetivo (OLIVEIRA, 1995).

Dessa forma, há de se reconhecer, também, que o resultado do clima organizacional irá depender do grau de motivação dos participantes, no sentido de que quanto mais motivados os membros, melhor será o clima da organização, as relações de satisfação, de animação, interesse, colaboração etc. (CHIAVENATO, 2009).

Logo, "o clima organizacional é favorável quando proporciona satisfação das necessidades pessoais dos participantes, produzindo elevação moral interno e desfavorável quando proporciona frustação daquelas necessidades" (CHIAVENATO, 2005, p. 53).

Com base nessa ideia, considerando que a forma de interação das pessoas - na relação com os colegas de trabalho e com o ambiente externo depende do grau de motivação e satisfação no trabalho de cada um, pode-se afirmar que os conceitos de clima organizacional, motivação e satisfação no trabalho estão diretamente ligados, no sentido em que um fator é o reflexo do outro. 
Assim, esse "sentimento" presente no ambiente de trabalho exerce grande influência na motivação e satisfação das pessoas ao mesmo tempo em que a motivação e a satisfação refletem no clima da organização. A relação entre ambos os conceitos é diretamente proporcional à medida que quanto melhor o clima organizacional, maior tende a ser o índice de satisfação e motivação de seus funcionários. Da mesma forma, um nível baixo de motivação irá resultar em um clima organizacional ruim.

O que, então, irá determinar o índice de satisfação das pessoas e o clima da empresa é o grau de atendimento dos fatores oferecidos pela empresa às necessidades pessoais de cada um de seus colaboradores, mas que irá refletir no coletivo.

Segundo Hasche (2011, p. 139), "o ambiente de trabalho e seus reflexos no resultado das empresas e satisfação dos colaboradores se tornaram vitais para garantir competitividade e satisfação nas companhias instaladas no Brasil". Além disso, pesquisas comprovam que uma empresa com um bom ambiente de trabalho tem mais facilidade em alcançar as suas metas e ter melhores resultados financeiros (HASCHE, 2011).

Por esse motivo, Luz (2003) afirma ser indispensável conhecer o que os funcionários pensam sobre a empresa e qual sua atitude em relação aos diferentes aspectos de uma organização, pois somente assim é possível melhorar a qualidade do ambiente de trabalho, da vida das pessoas e dos serviços prestados pela empresa. Para que isso tudo seja possível, deve haver a gestão do clima organizacional.

Diante da afirmativa de que a qualidade do ambiente de trabalho é essencial não só para garantir a satisfação dos colaboradores, mas também a competitividade da empresa no mercado, daí a grande importância de se medir essa qualidade por meio das pesquisas de clima.

\subsubsection{Pesquisa de clima organizacional}

Pesquisa de clima organizacional - também denominada de pesquisa de satisfação ou de ambiência - é um instrumento, normalmente no formato de questionário e/ ou entrevista, que consiste em obter as opiniões dos funcionários sobre diversos fatores de interesse da empresa (OLIVEIRA, 1995).

Em outras palavras, é um "levantamento de opiniões que caracteriza uma representação da realidade organizacional consciente, uma vez que retrata o 
que as pessoas acreditam estar acontecendo em determinado momento na organização" (BERGAMINI e CODA, 1997, p 99).

Embora existam várias técnicas para a realização de pesquisa de clima organizacional, deve-se escolher aquela mais adequada à situação. A técnica mais comum utilizada pelas empresas é o questionário, composto por um conjunto organizado de questões com o objetivo de revelar dados que se pretende descobrir (OLIVEIRA, 1995).

É crucial que a pesquisa garanta o anonimato dos respondentes a fim de evitar resultados mascarados devido ao receito de represálias, sendo necessária apenas a identificação do departamento onde trabalham (LUZ, 1995).

Para que seja possível medir o nível de satisfação dos empregados, as empresas elaboram pesquisas de clima organizacional, ou de ambiência, para saber o que seus funcionários pensam a respeito de cada valor oferecido pela empresa, a percepção quanto à liderança, aos benefícios oferecidos e às relações de trabalho como um todo, representando, assim, um diagnóstico sobre a situação atual da empresa, visando levantar problemas que mereçam correção (BERGAMINI e CODA, 1997).

Com o resultado da pesquisa feita com seus colaboradores, obtido após um processo de tabulação, análise e interpretação dos dados, a empresa terá as informações necessárias para identificar seus pontos positivos e negativos, sob o ponto de vida do trabalhador, e realizar um plano de ação adequado, com um propósito de melhoria (OLIVEIRA, 1995).

Hasche (2011, p. 144) ressalta que "o aspecto mais importante de uma pesquisa de clima é fazer uma análise detalhada dos resultados e criar um plano de ação". Ainda segundo a autora, esse plano de ação deverá contemplar tanto os aspectos corporativos da organização como um todo, quanto os aspectos específicos de cada uma das áreas. Essa divisão é necessária porque existem demandas comuns a todos os funcionários, mas também aquelas que são específicas de cada área, e, somente assim, será possível atender às expectativas de todos os respondentes.

Luz (1995, p. 42) lembra que "o diagnóstico deve ater-se mais aos aspectos internos da organização e menos aos aspectos ambientais, extrínsecos a ela".

Infelizmente, nem todas as empresas se preocupam em trabalhar os resultados da pesquisa e isso é altamente reprovável, pois, a partir do momento em que os funcionários são convocados a opinar sobre a empresa, suas práticas e políticas internas, relacionamento com chefia, entre outros fatores, cria-se uma 
expectativa em relação a futuras mudanças. Logo, se não há intenção de promover melhorias a partir de insatisfações, melhor nem realizar a pesquisa de clima (HASCHE, 2011).

Outro ponto de atenção além da necessidade de um plano de ação é a forma como deverá ser feita a comunicação de todas as etapas da pesquisa aos colaboradores.

Segundo Oliveira (1995), o relatório dos resultados da pesquisa deve ser divulgado para todos os funcionários da empresa de forma clara e sucinta, de modo que seja compreendido por todos os leitores.

Hasche (2011) acrescenta que os resultados da pesquisa, bem como o plano de ação a ser adotado, devem ser comunicados aos colaboradores de forma ágil e precisa. Uma comunicação mal feita sobre a própria pesquisa, seus propósitos, o trabalho de melhoria que será feito ou até mesmo a falta de divulgação de um cronograma com datas para cada etapa da pesquisa poderá resultar num baixo número de respondentes, demonstrando, assim, baixa credibilidade por parte dos funcionários para com a empresa.

Portanto, com base nas ideias apresentadas, a partir do momento em que uma empresa decide medir o índice de satisfação de seus funcionários por meio de pesquisa, deve estar disposta a ir até o final, realizando todas as etapas dentro do prazo estabelecido, mostrando um plano de ação capaz de trabalhar adequadamente os pontos de melhoria, preocupando-se, ao mesmo tempo, com a comunicação, pois fazer o que deve ser feito não é suficiente se os colaboradores não sabem o que está sendo feito, nem como está sendo feito. A realização disso tudo em conjunto é essencial para que a empresa passe credibilidade aos colaboradores e, quanto maior essa credibilidade, maior será a adesão à pesquisa e mais fiel será o resultado da pesquisa de clima à realidade da empresa. 


\section{Metodologia}

\subsection{Tipo de Pesquisa}

De acordo com VERGARA (2010), os tipos de pesquisa podem ser divididos quanto aos fins e meios.

Quanto aos fins, foi feita uma pesquisa descritiva, pois é o tipo de pesquisa que "expõe características de determinada população ou determinado fenômeno" (VERGARA, 2010, p. 42) e, portanto, atende melhor ao propósito deste trabalho que visa obter a opinião dos pesquisados quanto à sua percepção do estilo de liderança liberal e, assim, chegar a um resultado.

Como essa opinião dos respondentes foi coletada por meio de questionário aplicado, o tipo de pesquisa mais adequado, quanto aos meios, é a pesquisa de campo, cuja definição, conforme VERGARA (2010, p. 43), é "investigação empírica realizada no local onde ocorre ou ocorreu um fenômeno ou que dispõe de elementos para aplicá-lo. Pode incluir entrevistas, aplicação de questionários, testes e observação participante ou não".

\subsection{Universo e Amostra}

Entende-se por universo ou população como sendo o conjunto de elementos que possuem as características que serão objeto de estudo de um determinado trabalho. Amostra, por sua vez, é parte desse universo - ou população - segundo algum critério de representatividade. Existem dois tipos de amostra: probabilística e não-probabilística (VERGARA, 2010).

Diante desse conceito, neste trabalho, o universo é compreendido por todos os funcionários das empresas que serão escolhidas para serem analisadas quanto ao fenômeno a ser investigado. Devido à inviabilidade de se entrevistar todos, será escolhida uma amostra do tipo não-probabilística por acessibilidade. 


\subsection{Coleta de Dados}

Para a coleta de dados, foi elaborado um questionário semiestruturado contendo perguntas abertas e fechadas - aplicado ao público pertencente à amostra selecionada, por meio de um software online por motivo de praticidade e garantia de privacidade do respondente. Cabe ressaltar que o questionário foi submetido a um pré-teste, sendo enviado a um pequeno grupo de pessoas que não fez parte da amostra.

Quanto à estrutura do questionário, há, primeiramente, uma seção de apresentação aos respondentes, contendo uma breve explicação do propósito da pesquisa e da garantia de anonimato.

Após essa introdução, iniciou-se uma sequência de questões fechadas e abertas que visam verificar como o respondente percebe seu gestor imediato definindo o estilo de liderança que mais se assemelha a ele - e a eficácia desse estilo de liderança no que se refere às atividades desempenhadas e o comportamento das pessoas do departamento. Em seguida, pergunta-se abertamente ao respondente a respeito de sua opinião quanto ao motivo que leva um determinado gestor a adotar uma postura liberal, já que o foco deste trabalho está voltado à percepção sobre a liderança liberal. Para auxiliar o respondente nessa seção de perguntas, foi incluído ao questionário o Quadro 1 deste trabalho, com a definição dos estilos de liderança, segundo Chiavenato (2005, p.187).

As questões seguintes têm o objetivo de desvendar a percepção e o grau de satisfação do respondente em relação a seu líder e às políticas de liderança adotadas na empresa onde trabalha. Para isso, pergunta-se ao respondente se, em sua opinião, seu gestor possui as características necessárias para ser um bom líder, se sua forma de liderança contribui positivamente para sua satisfação no trabalho e se as indicações para ocupação de cargos gerenciais são feitas com base na meritocracia. Pergunta-se também sobre como acredita que seus colegas de trabalho - do mesmo departamento - percebem esse mesmo gestor, fazendo-se essas mesmas perguntas. As respostas são em grau de concordância, possibilitando discordar ou concordar parcial ou totalmente, ou não concordar nem discordar.

Para melhor compreender a percepção do respondente quanto às variáveis que influenciam a sua satisfação no trabalho, pediu-se que ordenasse os fatores que, em sua opinião, mais contribuíssem para a satisfação no trabalho. Os fatores sugeridos foram: benefícios, comunicação, condições físicas 
no trabalho, espírito de equipe, estabilidade no emprego, liderança, reconhecimento e recompensa, relação com o trabalho, remuneração e treinamento e desenvolvimento. Havia, ainda, a possibilidade de que o respondente acrescentasse qualquer outra variável que achasse pertinente. Posteriormente, o respondente deveria atribuir um peso - de zero a dez - que representasse a importância do fator "liderança" para a satisfação no trabalho.

Como complemento à pergunta sobre a percepção do respondente quanto ao fato de seu líder possuir as características necessárias para ser um bom líder, foi solicitado que esses atributos fossem ordenados do mais ao menos importante. As sugestões foram: autoconfiança, carisma, confiança na equipe, capacidade de delegar e dividir tarefas, capacidade de gerenciar conflitos, capacidade de reconhecer pessoas, envolvimento com o trabalho, flexibilidade e proatividade. Da mesma forma, perguntou-se também a característica que mais se destacava em um mau gestor e se o respondente a identificava em seu próprio gestor.

Por fim, vieram as perguntas para identificação do perfil do respondente, como sexo, faixa etária, tempo de mercado de trabalho e tipo de gestão da empresa onde trabalha atualmente. O questionário foi finalizado com um agradecimento pela participação e contribuição neste trabalho de conclusão de curso.

\subsection{Tratamento dos Dados}

Após a aplicação da pesquisa e obtenção dos questionários respondidos, ocorrerá a etapa de tratamento dos dados, quando as respostas obtidas serão analisadas e interpretadas de forma alinhada com o que se pretende alcançar neste trabalho, que é responder à pergunta-problema e chegar a uma conclusão.

Para isso, os dados serão tratados de forma quantitativa, usando-se procedimentos estatísticos para analisar as respostas das perguntas fechadas e abertas.

\subsection{Limitações do Método}

O método escolhido na aplicação da pesquisa possui suas limitações por representar apenas a opinião da amostra selecionada, podendo, assim, trazer um resultado divergente daquele que se obteria caso fosse feita a pesquisa com o universo ou população. 


\section{Apresentação e análise dos resultados}

\section{1. $\quad$ Descrições dos resultados}

Esta seção apresentará o resultado da pesquisa obtido após análise das respostas de cada respondente, verificando, inclusive, a existência de correlação entre os fatores analisados, levando-se em consideração o referencial teórico adotado neste estudo.

No total, 43 pessoas responderam ao questionário, cuja estrutura está detalhada no capítulo de Metodologia.

\subsubsection{Perfil dos respondentes}

Para identificar o perfil dos 43 respondentes da pesquisa, foram feitas perguntas sobre sexo, faixa etária, tempo de mercado de trabalho e tipo de gestão da empresa onde trabalha - pública ou privada - e os resultados obtidos estão representados em pontos percentuais conforme demonstrado no gráfico a seguir.

Gráfico 1: Perfil dos respondentes do questionário

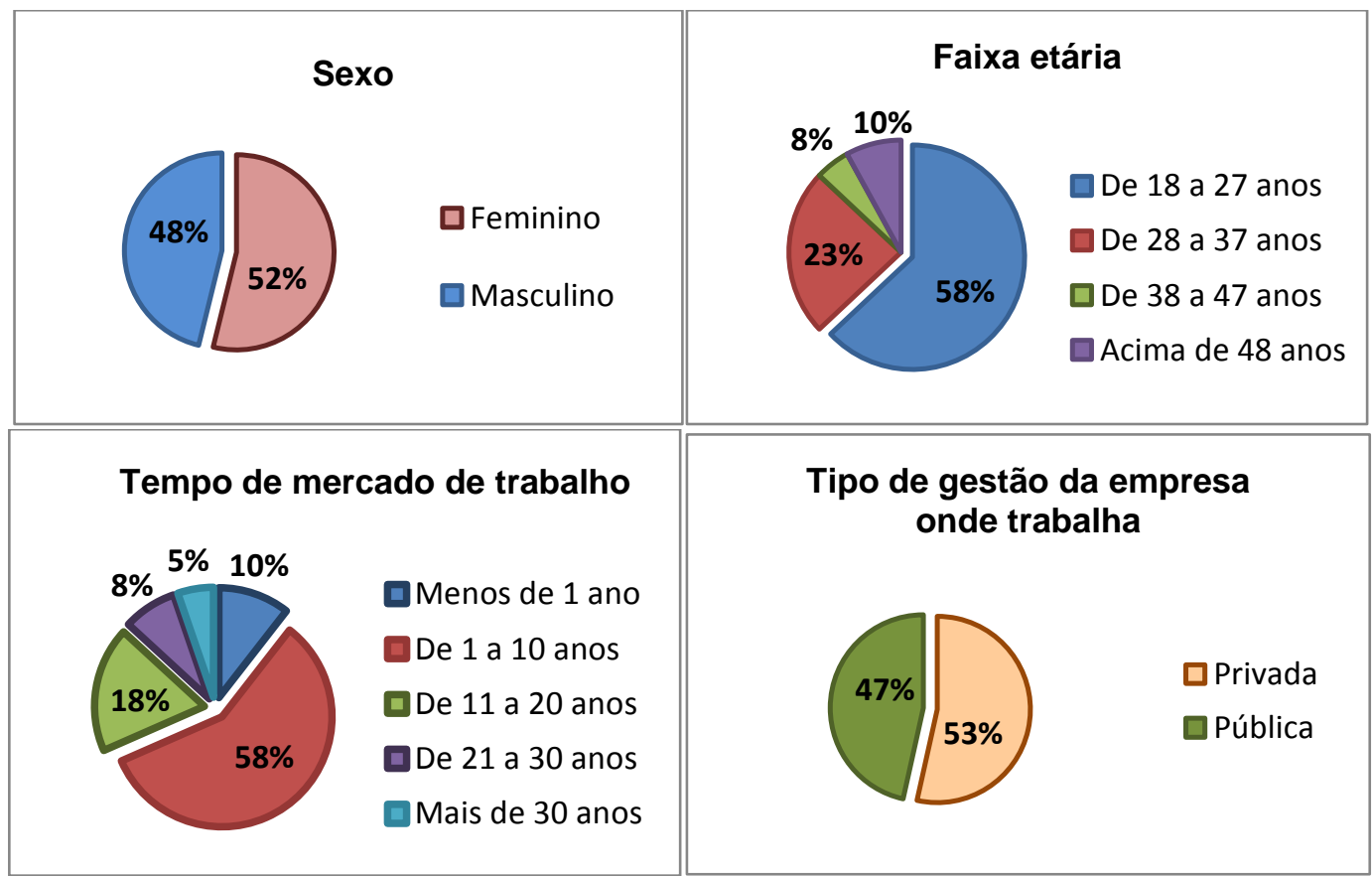

Fonte: Próprio Autor (2016) 
Como pode ser observado, dos 43 respondentes, 52\% são do sexo feminino e $48 \%$, do sexo masculino. Mais da metade dos respondentes possui idade concentrada na faixa mais jovem, dos 18 aos 27 anos, seguida pela segunda mais jovem, dos 28 aos 37 anos de idade, representando, juntos, $81 \%$ dos respondentes.

Devido a esse público bastante jovem, o tempo de mercado de trabalho acabou se concentrando em até 10 anos. Quanto ao tipo de gestão da empresa onde trabalham atualmente, $53 \%$ estão em empresas da iniciativa privada e $47 \%$ na administração pública direta ou indireta.

\subsubsection{Respostas sobre liderança e satisfação no trabalho}

Após apresentada aos respondentes a definição dos estilos de liderança conforme Chiavenato (2005, p.187), no que se refere à tomada de decisões, programação e divisão dos trabalhos e participação do líder, foram feitas as seguintes perguntas:

a) Qual estilo de liderança mais se assemelha ao de seu gestor imediato;

b) Qual estilo de liderança acredita ser o mais apropriado considerando as atividades exercidas no departamento;

c) Qual estilo de liderança acredita ser o mais apropriado considerando o comportamento das pessoas que trabalham no mesmo departamento;

d) Qual motivo de um gestor adotar uma postura de liderança liberal.

Dos 43 questionários obtidos, $60 \%$ identificam o perfil democrático em seus gestores, seguido pelos estilos autocrático e liberal, que representam, respectivamente, $21 \%$ e $19 \%$, conforme gráfico a seguir:

Gráfico 2: Estilo de liderança do gestor dos respondentes do questionário

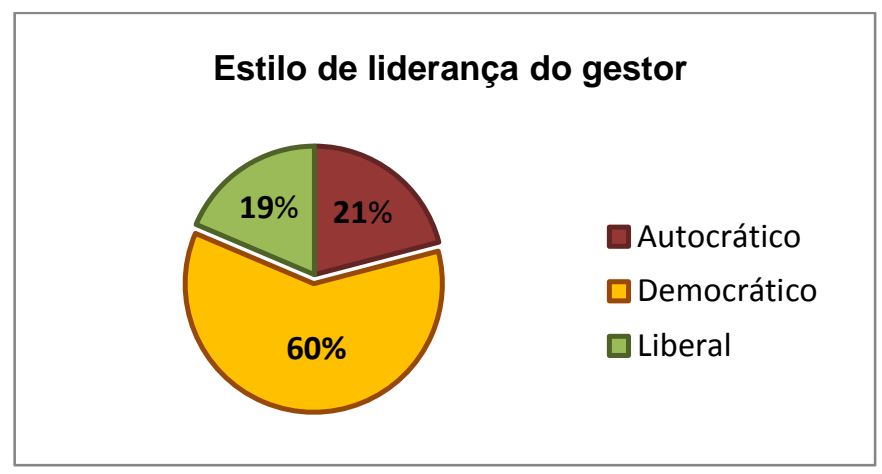

Fonte: Próprio Autor (2016) 
A segunda questão do questionário - que perguntava qual dos três estilos de liderança acreditavam ser o mais apropriado, levando-se em consideração as atividades exercidas no departamento onde trabalham e o comportamento dos seus colegas de trabalho - as respostas obtidas foram distribuídas conforme demonstrado na tabela 1. Essa pergunta permite saber não apenas qual estilo de liderança é o mais apropriado, na percepção do respondente, em ambas as situações apresentadas, mas também o quanto estão satisfeitos com o estilo de liderança adotado pelo gestor nessas situações, que fazem parte do dia a dia de trabalho.

Tabela 1: Percepção dos respondentes quanto aos estilos de liderança

\begin{tabular}{|c|c|c|c|c|c|c|c|c|c|c|}
\hline \multirow[b]{3}{*}{ Resposta } & \multicolumn{9}{|c|}{ Estilo de liderança do gestor do respondente } & \multirow{3}{*}{ Total } \\
\hline & \multicolumn{3}{|c|}{ Autocrático } & \multicolumn{3}{|c|}{ Democrático } & \multicolumn{3}{|c|}{ Liberal } & \\
\hline & A & D & $\mathbf{L}$ & A & D & $\mathbf{L}$ & A & D & $\mathbf{L}$ & \\
\hline $\begin{array}{l}\text { Considerando as } \\
\text { atividades exercidas no } \\
\text { departamento onde } \\
\text { trabalha, qual o estilo de } \\
\text { liderança acredita ser o } \\
\text { mais apropriado? }\end{array}$ & $0 \%$ & $89 \%$ & $11 \%$ & $7 \%$ & $93 \%$ & $0 \%$ & $0 \%$ & $75 \%$ & $25 \%$ & $100 \%$ \\
\hline $\begin{array}{l}\text { Considerando } \\
\text { comportamento das } \\
\text { pessoas que trabalham } \\
\text { no mesmo departamento } \\
\text { que você, qual o estilo de } \\
\text { liderança acredita ser o } \\
\text { mais apropriado? }\end{array}$ & $0 \%$ & $89 \%$ & $11 \%$ & $7 \%$ & $85 \%$ & $7 \%$ & $62 \%$ & $25 \%$ & $13 \%$ & $100 \%$ \\
\hline
\end{tabular}

Fonte: Próprio Autor (2016)

Como pôde ser verificado na tabela acima, quase uma totalidade dos respondentes - independentemente do perfil de liderança do gestor - aponta o estilo democrático como sendo o mais apropriado, levando-se em consideração as atividades exercidas no departamento onde trabalham.

Quando perguntados sobre o estilo de liderança mais apropriado, considerando o comportamento das pessoas que trabalham no mesmo departamento, as respostas são bastante semelhantes às da pergunta anterior já que a maioria continua concentrando a resposta no estilo democrático.

A exceção, porém, está nas respostas dos que possuem gestor com perfil liberal - todos oriundos de empresa da administração pública - que, apesar de apontarem uma preferência pelos estilos democrático e liberal no que se refere às atividades exercidas, possuem uma opinião bastante contrária no que se 
refere ao comportamento dos colegas de trabalho, preferindo, neste caso, o estilo autocrático.

Por outro lado, nenhum dos respondentes que possuem gestor com perfil autocrático acredita que esse é o estilo mais indicado em nenhuma das duas situações.

Os respondentes com gestor com perfil democrático são aqueles que apontam maior preferência por esse estilo de liderança de modo geral. Porém, quando o estilo de liderança é associado ao comportamento, ocorre uma queda em oito pontos percentuais, que acabam sendo distribuídos, igualitariamente, entre o autocrático e o liberal. Ao analisar a percepção desse público quanto aos estilos de liderança autocrático e liberal, pela soma dos percentuais, a maioria prefere o primeiro ao segundo, indicando uma preferência por um controle mais rígido a um mais brando, principalmente no que se refere às atividades exercidas no departamento.

Ao serem questionados sobre o motivo que levam um gestor a adotar o estilo de liderança liberal, as respostas obtidas foram variadas, conforme tabulado abaixo, entretanto é possível separá-las em percepções positivas, negativas, neutras e nulas.

Tabela 2: Percepção dos respondentes quanto ao gestor liberal

\begin{tabular}{|c|c|c|c|}
\hline \multirow[b]{2}{*}{ Respostas } & \multicolumn{3}{|c|}{$\begin{array}{l}\text { Estilo de liderança do gestor do } \\
\text { respondente }\end{array}$} \\
\hline & Autocrático & Democrático & Liberal \\
\hline $\begin{array}{l}\text { Confiança na equipe / Maturidade da } \\
\text { equipe }\end{array}$ & $67 \%$ & $65 \%$ & $38 \%$ \\
\hline $\begin{array}{l}\text { Comodidade / Falta de comprometimento } \\
\text { / Acúmulo de tarefas / Insegurança / } \\
\text { Limitação para liderar equipe / Equipe } \\
\text { com mais conhecimento que o gestor / } \\
\text { Desconhecimento dos processos / } \\
\text { Insatisfação com o cargo }\end{array}$ & $11 \%$ & $27 \%$ & $50 \%$ \\
\hline $\begin{array}{l}\text { Mundo mais dinâmico / Tomada de } \\
\text { decisão descentralizada / Mais tempo } \\
\text { para focar na gestão }\end{array}$ & $11 \%$ & $8 \%$ & $12 \%$ \\
\hline Não souberam responder & $11 \%$ & $8 \%$ & $0 \%$ \\
\hline
\end{tabular}

Fonte: Próprio Autor (2016)

Como muitos respondentes apontaram mais de um motivo que poderiam levar um gestor a adotar uma postura de liderança liberal, o somatório dos pontos percentuais não é igual a cem por cento. Conforme tabela acima, mais da metade justificou o fato de a equipe demonstrar um grau de maturidade 
suficiente para ganhar a confiança do gestor e, assim, ter mais liberdade ao conduzir suas tarefas e tomar decisões sem, necessariamente, precisar do auxílio da chefia.

Por outro lado, não se deve ignorar a percepção dos respondentes que enxergam a liderança liberal como comodidade, falta de comprometimento e insegurança do gestor, bem como uma limitação para liderar equipe, desconhecimento dos processos, acúmulo de atribuições gerenciais que o impossibilitam a dar a atenção necessária às tarefas executadas pela equipe que gerencia, ou até mesmo insatisfação com o cargo.

Importante notar que, com base nesses resultados, os respondentes com gestor liberal demonstram uma percepção muito mais negativa a respeito desse estilo de liderança, em comparação àqueles que vivenciam os estilos autocrático e democrático.

Os demais respondentes, que representam 18\% do total, não souberam ou não quiseram - responder ou atribuíram o motivo a fatores externos à vontade do gestor, como o fato de o mundo estar mais dinâmico ou a empresa praticar a tomada de decisão descentralizada.

As perguntas seguintes do questionário têm o objetivo de medir a satisfação dos funcionários em relação ao gestor e às políticas de liderança praticadas na empresa onde trabalham. As respostas desse grupo de funcionários com liderança autocrática, democrática e liberal estão representadas nas tabelas 3,4 e 5, respectivamente.

Tabela 3: Percepção e satisfação dos respondentes com gestor autocrático em relação a seu gestor e às políticas de liderança em sua empresa (continua)

\begin{tabular}{|c|c|c|c|c|c|c|}
\hline Afirmações & $\begin{array}{l}\text { Concor- } \\
\text { dância } \\
\text { Total }\end{array}$ & $\begin{array}{l}\text { Concor- } \\
\text { dância } \\
\text { Parcial }\end{array}$ & $\begin{array}{l}\text { Neutra- } \\
\text { lidade }\end{array}$ & $\begin{array}{l}\text { Discor- } \\
\text { dância } \\
\text { Parcial }\end{array}$ & $\begin{array}{l}\text { Discor- } \\
\text { dância } \\
\text { Total }\end{array}$ & Total \\
\hline $\begin{array}{l}\text { Seu gestor imediato possui as } \\
\text { características necessárias } \\
\text { para ser um bom líder. }\end{array}$ & $11 \%$ & $22 \%$ & $11 \%$ & $22 \%$ & $33 \%$ & $100 \%$ \\
\hline $\begin{array}{l}\text { As pessoas que trabalham no } \\
\text { mesmo departamento que você } \\
\text { acreditam que seu gestor } \\
\text { imediato possui as as } \\
\text { características necessárias } \\
\text { para ser um bom líder. }\end{array}$ & $0 \%$ & $11 \%$ & $22 \%$ & $33 \%$ & $33 \%$ & $100 \%$ \\
\hline $\begin{array}{l}\text { A forma de liderança de seu } \\
\text { gestor imediato contribui } \\
\text { positivamente para a sua } \\
\text { satisfação no trabalho. }\end{array}$ & $11 \%$ & $0 \%$ & $22 \%$ & $11 \%$ & $56 \%$ & $100 \%$ \\
\hline
\end{tabular}


Tabela 3: Percepção e satisfação dos respondentes com gestor autocrático em relação a seu gestor e às políticas de liderança em sua empresa (conclusão)

\begin{tabular}{lllllll}
\hline Afirmações & $\begin{array}{c}\text { Concor- } \\
\text { dância } \\
\text { Total }\end{array}$ & $\begin{array}{c}\text { Concor- } \\
\text { dância } \\
\text { Parcial }\end{array}$ & $\begin{array}{c}\text { Neutra- } \\
\text { lidade }\end{array}$ & $\begin{array}{c}\text { Discor- } \\
\text { dância } \\
\text { Parcial }\end{array}$ & $\begin{array}{c}\text { Discor- } \\
\text { dância } \\
\text { Total }\end{array}$ & Total \\
\hline $\begin{array}{l}\text { A forma de liderança de seu } \\
\text { gestor imediato contribui }\end{array}$ & & & & & & \\
positivamente para a satisfação & $0 \%$ & $0 \%$ & $33 \%$ & $33 \%$ & $33 \%$ & $100 \%$ \\
das pessoas do seu \\
departamento.
\end{tabular}

Fonte: Próprio Autor (2016)

De acordo com os resultados da tabela 3 , percebe-se que $55 \%$ dos respondentes que possuem gestor com liderança autocrática qualificam seu gestor de forma negativa, contra os 33\% que atribuem uma avaliação positiva. Quando perguntados da percepção de seus colegas de trabalho, o percentual chega a ser maior, sendo igual a $66 \%$. O aumento em pontos percentuais ocorre também na resposta "não concordo, nem discordo", provavelmente por preferirem não opinar acerca da percepção alheia.

Como reflexo da má avaliação dos gestores autocráticos, foi alto o percentual - de $67 \%$ - de respondentes que declararam que a forma de liderança do gestor contribui, negativamente, para a sua satisfação no trabalho e a de seus colegas. Apenas 11\% mostraram-se satisfeitos com seu gestor e afirmaram que sua forma de liderança contribui positivamente para sua própria satisfação no trabalho. Cabe ressaltar que esses 11\%, apesar de terem essa percepção positiva, acreditam que seus colegas de trabalho não compartilham desse mesmo pensamento, tanto que o percentual, nessa pergunta, foi igual a zero.

Nenhum respondente dessa seção concordou que as indicações para ocupação dos cargos gerenciais são feitas com base na meritocracia. A maioria - representada por $55 \%$ dos respondentes - discordou parcialmente ou totalmente da afirmação e o restante preferiu não concordar nem discordar da afirmação, mantendo-se neutros na resposta. 
Tabela 4: Percepção e satisfação dos respondentes com gestor democrático em relação a seu gestor e às políticas de liderança em sua empresa

\begin{tabular}{|c|c|c|c|c|c|c|}
\hline Afirmações & $\begin{array}{l}\text { Concor- } \\
\text { dância } \\
\text { Total }\end{array}$ & $\begin{array}{l}\text { Concor- } \\
\text { dância } \\
\text { Parcial }\end{array}$ & $\begin{array}{l}\text { Neutra- } \\
\text { lidade }\end{array}$ & $\begin{array}{l}\text { Discor- } \\
\text { dância } \\
\text { Parcial }\end{array}$ & $\begin{array}{l}\text { Discor- } \\
\text { dância } \\
\text { Total }\end{array}$ & Total \\
\hline $\begin{array}{l}\text { Seu gestor imediato possui as } \\
\text { características necessárias para } \\
\text { ser um bom líder. }\end{array}$ & $50 \%$ & $38 \%$ & $0 \%$ & $12 \%$ & $0 \%$ & $100 \%$ \\
\hline $\begin{array}{l}\text { As pessoas que trabalham no } \\
\text { mesmo departamento que você } \\
\text { acreditam que seu gestor } \\
\text { imediato possui as a } \\
\text { características necessárias para } \\
\text { ser um bom líder. }\end{array}$ & $31 \%$ & $38 \%$ & $19 \%$ & $12 \%$ & $0 \%$ & $100 \%$ \\
\hline $\begin{array}{l}\text { A forma de liderança de seu } \\
\text { gestor imediato contribui } \\
\text { positivamente para a sua } \\
\text { satisfação no trabalho. }\end{array}$ & $54 \%$ & $31 \%$ & $8 \%$ & $8 \%$ & $0 \%$ & $100 \%$ \\
\hline $\begin{array}{l}\text { A forma de liderança de seu } \\
\text { gestor imediato contribui } \\
\text { positivamente para a satisfação } \\
\text { das pessoas do seu } \\
\text { departamento. }\end{array}$ & $35 \%$ & $50 \%$ & $4 \%$ & $12 \%$ & $0 \%$ & $100 \%$ \\
\hline $\begin{array}{l}\text { As indicações para ocupação } \\
\text { de cargos gerenciais na } \\
\text { empresa onde você trabalha } \\
\text { são feitas com base na } \\
\text { meritocracia. }\end{array}$ & $19 \%$ & $27 \%$ & $15 \%$ & $19 \%$ & $19 \%$ & $100 \%$ \\
\hline
\end{tabular}

Fonte: Próprio Autor (2016)

Como pode ser claramente percebido, as respostas dos respondentes com gestão democrática foram bastante diferentes daqueles com gestão autocrática. Ao responderem se seu gestor imediato possui as características necessárias para ser um bom líder, o grau de concordância foi relativamente alto, pois $88 \%$ responderam afirmativamente. Apenas $12 \%$ discordaram de forma parcial. Esses mesmos resultados tenderam a se repetir na pergunta a respeito da percepção do respondente quanto à percepção de seus colegas de trabalho, pois a distorção se deve ao fato de muitos terem preferido não opinar nesse quesito, assinalando a opção neutra, de "não concordo, nem discordo".

Não coincidentemente, o percentual de respondentes satisfeitos com seu líder - por acreditarem que possui qualidades que o credencia para essa função - aponta que sua forma de liderar contribui de forma positiva para a sua satisfação no trabalho. Mais uma vez, os resultados tendem a se assemelhar aos obtidos na pergunta voltada para a percepção dos colegas de trabalho. Importante ressaltar que nenhum respondente demonstrou total insatisfação - 
apenas parcial e, ainda assim, um percentual relativamente pequeno - em relação à liderança e acreditam que seus colegas de trabalho possuem a mesma opinião.

$\mathrm{Na}$ última pergunta dessa seção, que questiona a opinião do respondente quanto ao fato de as indicações na empresa onde trabalham serem feitas de acordo com a meritocracia, os resultados estão quase que igualitariamente distribuídos, significando que, mesmo aqueles que reconhecem que seu gestor é um bom líder e, consequentemente, qualificado para tal função gerencial, outros gestores de outros departamentos da empresa onde trabalham talvez não possuam essa capacitação ou, então, a variável "qualificação" costuma pesar pouco no momento de decidirem quem será nomeado ao cargo.

Tabela 5: Percepção e satisfação dos respondentes com gestor liberal em relação a seu gestor e às políticas de liderança em sua empresa

\begin{tabular}{|c|c|c|c|c|c|c|}
\hline Afirmações & $\begin{array}{l}\text { Concor- } \\
\text { dância } \\
\text { Total }\end{array}$ & $\begin{array}{l}\text { Concor- } \\
\text { dância } \\
\text { Parcial }\end{array}$ & $\begin{array}{l}\text { Neutra- } \\
\text { lidade }\end{array}$ & $\begin{array}{l}\text { Discor- } \\
\text { dância } \\
\text { Parcial }\end{array}$ & $\begin{array}{l}\text { Discor- } \\
\text { dância } \\
\text { Total }\end{array}$ & Total \\
\hline $\begin{array}{l}\text { Seu gestor imediato possui as } \\
\text { características necessárias } \\
\text { para ser um bom líder. }\end{array}$ & $12,5 \%$ & $0 \%$ & $0 \%$ & $12,5 \%$ & $75 \%$ & $100 \%$ \\
\hline $\begin{array}{l}\text { As pessoas que trabalham no } \\
\text { mesmo departamento que você } \\
\text { acreditam que seu gestor } \\
\text { imediato possui ar as } \\
\text { características necessárias } \\
\text { para ser um bom líder. }\end{array}$ & $12,5 \%$ & $0 \%$ & $0 \%$ & $62,5 \%$ & $25 \%$ & $100 \%$ \\
\hline $\begin{array}{l}\text { A forma de liderança de seu } \\
\text { gestor imediato contribui } \\
\text { positivamente para a sua } \\
\text { satisfação no trabalho. }\end{array}$ & $12,5 \%$ & $0 \%$ & $0 \%$ & $12,5 \%$ & $75 \%$ & $100 \%$ \\
\hline $\begin{array}{l}\text { A forma de liderança de seu } \\
\text { gestor imediato contribui } \\
\text { positivamente para a satisfação } \\
\text { das pessoas do seu } \\
\text { departamento. }\end{array}$ & $12,5 \%$ & $0 \%$ & $0 \%$ & $50 \%$ & $37,5 \%$ & $100 \%$ \\
\hline $\begin{array}{l}\text { As indicações para ocupação } \\
\text { de cargos gerenciais na } \\
\text { empresa onde você trabalha } \\
\text { são feitas com base na } \\
\text { meritocracia. }\end{array}$ & $0 \%$ & $0 \%$ & $0 \%$ & $0 \%$ & $100 \%$ & $100 \%$ \\
\hline
\end{tabular}

Fonte: Próprio Autor (2016)

Pelos resultados da tabela $5,87,5 \%$ do total de respondentes com gestor liberal afirmam não possuir um bom líder, pois discordaram da afirmação que diz 
que "seu gestor imediato possui as características necessárias para ser um bom líder".

Consequentemente, esses mesmos respondentes assinalaram que a forma de liderança que vivenciam contribui negativamente para a sua satisfação no trabalho. Quando perguntados sobre a percepção dos colegas de trabalho, continuaram mantendo a discordância, porém majoritariamente de forma parcial.

No que se refere às indicações para ocupação de cargos gerenciais na empresa onde trabalham, todos responderam que não ocorrem com base na meritocracia.

Ainda com o objetivo de medir o quanto o fator "liderança" contribui para a satisfação - ou insatisfação - no trabalho, foi solicitado que o respondente atribuísse um peso, em uma escala de zero a dez, a essa variável, onde quanto maior o peso, maior a importância ou contribuição da liderança para a satisfação no trabalho. Os resultados obtidos estão na tabela a seguir.

Tabela 6 - Contribuição do fator "liderança" para a satisfação no trabalho

\begin{tabular}{c|ccc}
\hline & \multicolumn{3}{|c}{ Estilo de liderança do gestor do respondente } \\
\hline Peso & Autocrático & Democrático & Liberal \\
\hline 10 & $22 \%$ & $4 \%$ & $0 \%$ \\
9 & $11 \%$ & $23 \%$ & $25 \%$ \\
8 & $22 \%$ & $27 \%$ & $75 \%$ \\
7 & $33 \%$ & $27 \%$ & $0 \%$ \\
6 & $0 \%$ & $12 \%$ & $0 \%$ \\
5 & $11 \%$ & $8 \%$ & $0 \%$ \\
\hline Total & $\mathbf{1 0 0} \%$ & $\mathbf{1 0 0} \%$ & $\mathbf{1 0 0} \%$ \\
\hline
\end{tabular}

Fonte: Próprio Autor (2016)

A nota máxima obtida do grupo de respondentes com liderança autocrática e democrática foi 10 e a mínima, 5. A média ficou em 7,9 e 7,6, respectivamente, e a mediana, em 8 em ambos os casos. Já no grupo daqueles com liderança liberal, os pesos foram apenas 8 e 9, com média e 8,25 e mediana 8. A distribuição das notas obtidas está demonstrada na tabela 6.

Para melhor compreender os motivos pelos quais alguns não atribuíram um peso muito grande para esse fator, foi solicitado, então, que o respondente ordenasse, do mais ao menos importante, os fatores que mais contribuem para a sua satisfação no trabalho. 
Os fatores listados foram: benefícios, comunicação, condições físicas no trabalho, espírito de equipe, estabilidade no emprego, liderança, reconhecimento e recompensa, relação com o trabalho, remuneração, e treinamento e desenvolvimento. Havia, ainda, dois campos em branco para o respondente incluir e ordenar a variável que julgasse pertinente. O ranqueamento dos fatores que mais contribuem para a satisfação no trabalho, na opinião dos respondentes com liderança autocrática, democrática e liberal ficou da seguinte forma, conforme demonstrado na tabela 7.

Tabela 7 - Fatores que mais contribuem para a satisfação no trabalho

\begin{tabular}{l|ccc}
\hline & \multicolumn{3}{|c}{ Estilo de liderança do gestor do } \\
respondente
\end{tabular}

Os funcionários com liderança autocrática e democrática acreditam que reconhecimento e recompensa e remuneração são, respectivamente, os fatores que mais contribuem para a satisfação no trabalho. Em terceiro lugar, vem a liderança. A partir do quarto lugar, a percepção passa a destoar. Enquanto o primeiro grupo reconhece mais a importância da estabilidade e comunicação no que diz respeito a satisfação no trabalho, o segundo coloca à frente fatores como benefícios e a relação com o trabalho em si, ou seja, a satisfação com as tarefas realizadas. Treinamento e desenvolvimento foram colocados como o menos importante por ambos os grupos.

Já aqueles com liderança liberal ordenaram de forma bastante singular. A relação com o trabalho em si ficou em primeiro lugar, mostrando-se como o fator de maior impacto na satisfação no trabalho, na opinião desse grupo. Em 
seguida, ficaram reconhecimento e recompensa, espírito de equipe, estabilidade, benefícios e, somente em sexto lugar, a liderança, ficando à frente de remuneração, que foi o segundo fator mais votado pelos demais grupos. Condições físicas no trabalho, treinamento e desenvolvimento e comunicação foram os fatores menos priorizados.

Ainda com o objetivo de explorar a percepção do respondente sobre o fator liderança, foi solicitado também que ordenasse as características que mais se destacavam em um bom gestor. As qualidades sugeridas foram: autoconfiança, carisma, confiança na equipe, proatividade, flexibilidade, capacidade de delegar e dividir tarefas, capacidade de gerenciar conflitos, capacidade de reconhecer pessoas e envolvimento com o trabalho. Havia, ainda, a possibilidade de o respondente acrescentar características que julgasse pertinente. Os resultados obtidos estão tabulados a seguir.

Tabela 8: Características que mais se destacam em um bom líder

\begin{tabular}{l|ccc}
\hline & \multicolumn{3}{|c}{ Estilo de liderança do gestor do } \\
respondente & \multicolumn{2}{c}{ Liberal } \\
\hline Respostas & Autocrático & Democrático & $9^{\circ}$ \\
\hline Autoconfiança & $6^{\circ}$ & $7^{\circ}$ & $8^{\circ}$ \\
Carisma & $3^{\circ}$ & $6^{\circ}$ & $1^{\circ}$ \\
Capacidade de delegar e dividir tarefas & $1^{\circ}$ & $4^{\circ}$ & $4^{\circ}$ \\
Capacidade de reconhecer pessoas & $4^{\circ}$ & $2^{\circ}$ & $5^{\circ}$ \\
Capacidade de gerenciar conflitos & $2^{\circ}$ & $3^{\circ}$ & $6^{\circ}$ \\
Confiança na equipe & $5^{\circ}$ & $1^{\circ}$ & $3^{\circ}$ \\
Envolvimento com o trabalho & $8^{\circ}$ & $5^{\circ}$ & $7^{\circ}$ \\
Flexibilidade & $9^{\circ}$ & $9^{\circ}$ & $2^{\circ}$ \\
Proatividade & $7^{\circ}$ & $8^{\circ}$ &
\end{tabular}

Fonte: Próprio Autor (2016)

Capacidade de delegar e de dividir tarefas é, na opinião dos respondentes com gestor autocrático e liberal, a característica que mais se destaca em um bom líder. No caso do primeiro grupo, essa qualidade é seguida pela capacidade de gerenciar conflitos, pelo carisma e pela capacidade de reconhecer pessoas. Apesar de confiança na equipe ter ficado, de modo geral, quinto lugar, foi a qualidade que ficou colocada em primeiro lugar por mais vezes por esse público. As que menos se destacam, em comparação com as demais qualidades, são proatividade, envolvimento com o trabalho e flexibilidade. 
Os respondentes com gestor democrático destacaram a confiança na equipe como a qualidade mais importante em um bom líder, seguido pela capacidade de reconhecer pessoas, de gerenciar conflitos e de delegar e dividir tarefas. Para esse grupo, as que menos se destacam são autoconfiança, proatividade e flexibilidade.

Já aqueles com gestor liberal, apesar de terem concordado com o primeiro grupo ao considerar a capacidade de delegar e dividir tarefas como sendo a característica que mais se destaca em um bom líder, as demais priorizações ficaram bastante diferentes das opiniões dos outros dois grupos analisados. Enquanto proatividade e envolvimento com o trabalho não foram priorizadas pelos demais públicos, esses dois fatores foram considerados de grande destaque. Aliás, apesar da qualidade "capacidade de delegar e dividir tarefas" ter ficado em primeiro lugar na média, foi justamente "proatividade" que por mais vezes ficou em primeiro lugar no resultado.

Da mesma forma que se perguntou sobre as características que fazem um bom líder, perguntou-se também o que mais se destaca em um mau gestor e se seu gestor possuía tal característica. O campo para resposta da primeira pergunta era livre. As respostas obtidas estão tabuladas a seguir, juntamente com o percentual que representa a quantidade de vezes que cada resposta se repetiu.

Tabela 9: Características que mais se destacam em um mau gestor

\begin{tabular}{l|ccc}
\hline & \multicolumn{3}{|c}{ Estilo de liderança do gestor do } \\
respondente
\end{tabular}

Fonte: Próprio Autor (2016) 
Tabela 10: Percentual de respondentes que identificam, em seu gestor, a característica destacada por eles na pergunta anterior

\begin{tabular}{ccc}
\hline \multicolumn{3}{c}{ Estilo de liderança do gestor do respondente } \\
\hline Autocrático & Democrático & Liberal \\
\hline $78 \%$ & $12 \%$ & $75 \%$ \\
\hline
\end{tabular}

Fonte: Próprio Autor (2016)

Independentemente do estilo de liderança vivenciado pelos respondentes, algumas características consideradas de maior destaque em um mau gestor se repetiam. Os respondentes com gestor democrático são os que apresentaram respostas mais variadas e, por isso, conseguiram destacar pontos levantados pelos demais grupos, de gestão autocrática e liberal, que, por sua vez, demonstraram percepção bastante contrária uma da outra, inexistindo interseção de respostas.

Percebe-se que os respondentes que vivenciam uma gestão autocrática foram os que mais destacaram como pontos negativos o autoritarismo em excesso que, muitas vezes, vem acompanhado de arrogância, falta de empatia e controle emocional, incapacidade de ouvir a equipe e comunicar-se com ela. Esse tipo de comportamento demonstra a incapacidade do gestor de lidar com pessoas. Desse grupo de respondentes, $78 \%$ afirmam que essas características estão presentes em seu gestor imediato.

As respostas daqueles com gestão democrática tiveram suas respostas mais pulverizadas e, além de terem identificado algumas das características levantadas pelo grupo anterior, foram acrescentadas algumas incapacidades como a de delegar tarefas, gerenciar conflitos e reconhecer pessoas, além de falta de confiança na equipe e proatividade. Ao contrário dos demais grupos, apenas uma pequena minoria de $12 \%$ afirma que seu gestor possui tais defeitos.

Já o último grupo, que vivencia uma gestão liberal, apontou como a pior característica de um mau gestor o desinteresse com o trabalho desempenhado por sua equipe, a falta de proatividade e de perfil gerencial. Os que identificaram esses problemas representam os $75 \%$ que afirmaram conviver com um gestor com essa postura. Os demais respondentes que afirmaram que a falta de confiança é a característica que mais se destaca em um mau gestor não identificaram esse problema em seu gestor.

Vale observar que cada uma das características apresentadas pelos respondentes possui algum tipo de correlação com alguma outra. Por exemplo, a insegurança de um gestor pode torná-lo não proativo, desinteressado com trabalho e, consequentemente, passar uma imagem de que não possui perfil 
gerencial. Da mesma forma, o autoritarismo em excesso pode torna-lo incapaz de lidar com pessoas e reconhecê-las, quando necessário.

Além disso, percebe-se que, enquanto os profissionais de liderança autocrática estão insatisfeitos com o excesso de atitude, porém controladora, de seus gestores, os de liderança liberal tem sua insatisfação voltada para a falta de atitude e omissão em relação às suas responsabilidades e atribuições. 


\section{Conclusões e recomendações para novos estudos}

\subsection{Conclusões}

Este trabalho teve como objetivo apresentar a percepção de funcionários de empresas da administração pública e privada, e que vivenciam diferentes estilos de liderança, em relação ao gestor com postura de liderança liberal e os reflexos nos níveis de satisfação do trabalho.

Para que o estudo fosse possível, foram feitas pesquisas bibliográficas e de campo com pessoas atualmente inseridas no mercado de trabalho. $O$ questionário foi elaborado no software Qualtrics e preenchido por uma amostra de 43 pessoas escolhidas por acessibilidade. Os dados obtidos foram interpretados visando estabelecer uma relação entre as variáveis analisadas e, posteriormente, atender ao objetivo deste trabalho.

Os resultados apresentados no capítulo anterior demonstraram que o estilo de liderança liberal foi considerado o menos apropriado, levando-se em consideração as tarefas desempenhadas no departamento onde trabalham ou o comportamento de seus colegas de trabalho. O ideal, segundo opinião dos respondentes, seria o democrático, que atua de forma moderada e, portanto, mais aceitável pela maioria - por aqueles que não toleram o estilo autoritário do autocrático ou laissez-faire do liberal.

Apesar de a liderança liberal não ter sido considerada o modelo ideal nas situações acima apresentadas, a percepção do gestor com postura liberal é tida, pela maioria dos respondentes, como positiva, pois se acredita que um gestor age dessa forma por confiar na sua equipe, que possui maturidade suficiente para merecer liberdade.

Essa maioria, porém, declara possuir gestores autocráticos ou democráticos e, provavelmente, ainda não teve a experiência ser liderada por um gestor com postura liberal, até mesmo pela faixa etária dos respondentes da pesquisa, que se concentra nos dezoito aos vinte e sete anos de idade, e do tempo de mercado de trabalho declarado, de até dez anos.

Logo, o motivo dessa rejeição está relacionado a uma postura negativa adotada por alguns gestores liberais, que demonstram insegurança, falta de proatividade, desinteresse com 0 trabalho desempenhado por seus 
subordinados, incapacidade de tomar decisões de cunho gerencial, entre outros problemas, passando uma imagem de mau gestor, que é transmitida e percebida, principalmente, por seus subordinados. Essas características foram identificadas por alguns respondentes, porém majoritariamente por aqueles que vivenciam esse estilo de liderança.

Como consequência dessa situação, aqueles que vivenciam uma liderança liberal foram os que mais demonstraram insatisfação em relação a seu próprio gestor, na medida em que não o reconhecem como um bom líder e declaram que sua forma de liderança contribui, de forma negativa, para sua satisfação no trabalho, além de acreditarem - mais que os demais respondentes - que as indicações para ocupação de cargos gerenciais não são feitas de acordo com a meritocracia.

Apesar de considerarem que fatores como relação com o trabalho, reconhecimento e recompensa, espírito de equipe, estabilidade e benefícios são mais importantes que liderança quando se fala em satisfação no trabalho, os que possuem gestor liberal foram aqueles que atribuíram maior nota - com média de 8,25 - quando perguntados sobre o peso do fator de liderança na satisfação ou insatisfação - no trabalho.

Por fim, com base nessas conclusões, pode-se dizer que o objetivo deste trabalho foi alcançado, uma vez que foi possível estabelecer uma relação entre o estilo de liderança liberal e a satisfação no trabalho, levando-se em consideração a percepção de diferentes perfis de funcionários, com variadas idades e tempo de mercado de trabalho, provenientes de empresas com diferentes modelos de gestão e políticas internas.

\subsection{Recomendações para novos estudos}

Considera-se que o estudo trouxe contribuições para um melhor entendimento a respeito dos reflexos de uma boa ou má liderança na satisfação ou insatisfação no trabalho, atendendo, assim, aos objetivos propostos.

Todavia, tendo em vista a amostra utilizada, do tipo não-probabilística por acessibilidade, o número de respondentes obtido, assim como o perfil do público alcançado, podem não ter sido suficientes para representar a real percepção quanto ao estilo de liderança liberal e sua relação com os níveis de satisfação no trabalho.

Diante disso, recomenda-se que essa pesquisa seja aplicada a um público mais miscigenado, com idade e tempo de mercado de trabalho mais 
avançados, e, também, a um número maior de profissionais com gestores autocráticos e liberais, de forma que a comparação entre a percepção daqueles que vivenciam diferentes estilos de liderança seja mais justa.

Assim, além de possibilitar o aprofundamento do estudo, será possível comparar os resultados de ambos os trabalhos realizados e, em seguida, verificar se há alguma divergência apenas por utilizar uma amostra maior e mais miscigenada. 


\section{Referências Bibliográficas}

BERGAMINI, Cecilia W.; CODA, Roberto. Psicodinâmica da vida organizacional: motivação e liderança. 2.ed. São Paulo: Atlas, 1997.

BROXADO, Sílvio. A verdadeira motivação na empresa: entendendo a psicologia organizacional e dicas para a motivação no dia-a-dia das empresas. Rio de Janeiro: Qualitymark, 2001.

CASTILHO, Áurea. Liderando grupos: um enfoque gerencial. 3. ed. Rio de Janeiro: Qualitymark, 2005.

CAVALCANTI, Vera Lucia et al. Liderança e motivação. 3. ed. Rio de Janeiro: FGV, 2009.

CHIAVENATO, Idalberto. Gerenciando com as Pessoas: transformando o executivo em um excelente gestor de pessoas. Rio de Janeiro: Elsevier, 2005.

Recursos Humanos: o capital humano das organizações. 9.ed. Rio de Janeiro: Elsevier, 2009.

FERREIRA, Patrícia Ítala. Clima organizacional e qualidade de vida no trabalho. Rio de Janeiro: Grupo GEN, 2013.

GRIFFIN, Ricky; Moorhead, Gregory. Fundamentos do comportamento organizacional. Tradução Fernando Moreira Lea, André Siqueira Ferreira. São Paulo: Ática, 2006.

HASCHE, Marcia. Clima sem rodeios. Rio de Janeiro: Sinergia, 2011. 
LOPES, Tomás de Vilanova Monteiro. Motivação no trabalho. 1. ed. Rio de Janeiro: FGV, 1980.

LUZ, Ricardo. Clima organizacional. Rio de Janeiro: Qualitymark, 1995.

. Gestão do clima organizacional. Rio de Janeiro: Qualitymark, 2003.

OLIVEIRA, Marco A. Pesquisas de clima interno nas empresas: o caso dos desconfiômetros avariados. São Paulo: Nobel, 1995.

ROBBINS, Stephen P.; JUDGE, Timothy A.; SOBRAL, Filipe. Comportamento organizacional: teoria e prática no contexto brasileiro. 14. ed. São Paulo: Pearson Prentice Hall, 2010.

RODRIGUES, Marcus Vinícius Carvalho. Qualidade de vida no trabalho: evolução e análise no nível gerencial. 2. ed. Rio de Janeiro: Vozes, 1994.

SEBRAE. Três estilos de liderança e os impactos junto aos colaboradores. Disponível em: http://www.sebrae.com.br/sites/PortalSebrae/artigos/Tr\%C3\%AAs-estilosde-lideran\%C3\%A7a-e-os-impactos-junto-aos-colaboradores. Acesso em: 20 set. 2015.

SILVA, Walmir R.; RODRIGUES, Cláudia Medianeira C. Motivação nas organizações. São Paulo: Atlas 2007.

VERGARA, Sylvia. Gestão de Pessoas. 8. ed. São Paulo: Atlas, 2009.

. Projetos e Relatórios de Pesquisa em Administração. 12. Ed. São Paulo: Atlas, 2010. 
YUKL, Gary. Leadership in organizations. 8. Ed. Nova Jersey: Pearson, 2013. 


\section{Apêndice - Questionário}

1. Qual estilo de liderança mais se assemelha ao de seu gestor imediato?

- Autocrático

- Democrático

- Liberal

2. Considerando as atividades exercidas no departamento onde trabalha, qual estilo de liderança acredita ser o mais apropriado?

- Autocrático

- Democrático

- Liberal

3. Considerando o comportamento das pessoas que trabalham no mesmo departamento que você, qual estilo de liderança acredita ser o mais apropriado?

- Autocrático

- Democrático

- Liberal

4. Na sua opinião, o que faz com que um gestor adote um estilo de liderança liberal?

5. Selecione a opção que representa seu grau de concordância com cada uma das afirmativas abaixo:

5.1. Seu gestor imediato possui as características necessárias para ser um bom líder.

- Concordo totalmente

- Concordo parcialmente

- Não concordo nem discordo

- Discordo parcialmente

- Discordo totalmente 
5.2. As pessoas que trabalham no mesmo departamento que você acreditam que seu gestor possui as características necessárias para ser um bom líder.

- Concordo totalmente

- Concordo parcialmente

- Não concordo nem discordo

- Discordo parcialmente

- Discordo totalmente

5.3. A forma de liderança do seu gestor imediato contribui positivamente para a sua satisfação no trabalho

- Concordo totalmente

- Concordo parcialmente

- Não concordo nem discordo

- Discordo parcialmente

- Discordo totalmente

5.4. A forma de liderança do seu gestor imediato contribui positivamente para a satisfação das pessoas do seu departamento

- Concordo totalmente

- Concordo parcialmente

- Não concordo nem discordo

- Discordo parcialmente

- Discordo totalmente

5.5. As indicações para ocupação de cargos gerenciais na empresa onde você trabalha são feitas com base na meritocracia.

- Concordo totalmente

- Concordo parcialmente

- Não concordo nem discordo

- Discordo parcialmente

- Discordo totalmente

6. Ordene os fatores que, na sua opinião, mais contribuem para a satisfação ou insatisfação no trabalho.

- Benefícios

- Comunicação 
- Condições físicas no trabalho

- Espírito de equipe

- Estabilidade no emprego

- Liderança

- Reconhecimento e recompensa

- Relação com o trabalho

- Remuneração

- Treinamento e desenvolvimento

- Outros (opcional)

7. Em uma escala de 0 a 10, qual peso você atribui ao item "liderança" na importância para a satisfação no trabalho?

8. Ordene as características que, na sua opinião, mais se destacam em um bom gestor.

- Autoconfiança

- Carisma

- Capacidade e delegar e dividir tarefas

- Capacidade de gerenciar conflitos

- Capacidade de reconhecer pessoas

- Confiança na equipe

- Envolvimento com o trabalho

- Flexibilidade

- Proatividade

- Outros (opcional)

9. Escreva as características que, na sua opinião, mais se destaca em um mau gestor.

10. Seu gestor possui a característica descrita na questão 9?

11. Qual seu sexo?

- Feminino

- Masculino 
12. Qual sua faixa etária?

- De 18 a 27 anos de idade

- De 28 a 37 anos de idade

- De 38 a 47 anos de idade

- A partir de 48 anos de idade

13. Quanto tempo de mercado de trabalho?

- Menos de 1 ano

- De 1 a 10 anos

- De 11 a 20 anos

- De 21 a 30 anos

- Mais de 30 anos

14. Qual tipo de gestão da empresa onde trabalha?

- Administração privada

- Administração pública (direta ou indireta) 